\title{
Kent Yaşamında Dış Mekân Süs Bitkilerinin Önemi ve Kullanıcı Tercihleri: Kilis Örneği
}

\author{
Saliha TAŞÇIOĞLU ${ }^{1}$, Meryem KUZUCU² \\ ${ }^{1}$ Kilis 7Aralık Üniversitesi, Kilis Meslek Yüksek Okulu, Park ve Bahçe Bitkileri Bölümü, 79000, Kilis \\ ${ }^{2}$ Kilis 7Aralık Üniversitesi, Kilis Meslek Yüksek Okulu, Bitkisel ve Hayvansal Üretim Bölümü, 79000, Kilis
}

\section{Öz}

Çalışmanın amacı Kilis kenti kentsel açık alanlarda yer alan bitkilerin kullanıcılar açısından tercih durumlarını ve süs bitkileri ile ilgili genel yaklaşımlarını belirlemektir. Bu amaçla, en az 3 yıldır şehirde ikamet ediyor olmak kaydıyla belirlenmiş olan, 100 katılımcı üzerinde bir anket çalışması gerçekleştirilmiştir. Ankete katkı sağlayanların çoğunluğu, 18-25 yaş aralığında olup, Yüksekokul veya Fakülte öğrencisidir. Katılımcılardan 10 farklı dış mekân süs bitkisini, kendi beğenileri doğrultusunda sıralamaları istenmiștir. Çalışma sonunda ilk sırada en çok tercih edilen tür \%22 ile Narcissus sp.(nergis), en az tercih edilen tür ise $\% 2$ ile Chaenomeles japonica (bahar dalı) olarak belirlenmiştir. Bitkilerle ilgili tercih edilen özellikler incelendiğinde en yüksek değerler kokulu olması (\%74), görsellik (\%65), renkli olması (\%37) olarak sıralanmaktadır. Sonuçlar kent içi yeşil alanlarda kullanılacak olan bitkilerin, kullanıcı istekleri doğrultusunda belirlenmesinin yanı sıra, estetik ve işlevsel özellikleri ile doğal çevreye uyum sağlayabilen türlerinin kullanımının yaygınlaştırılması gerektiğini vurgular niteliktedir.

Anahtar Kelimeler: Kullanıcı tercihi, süs bitkileri, Kilis, bitkisel tasarım, dış mekân

\section{Importance of Outdoor Ornamental Plants for Urban Life and User Preferences: Case of Kilis}

\begin{abstract}
The aim of this study is to determine the preferences of the plants in Kilis urban open spaces and to identify general user attitudes towards the ornamental plants. For this purpose, a questionnaire was conducted with 100 participants who have been living in the city for at least 3 years. The majority of the participants who participated in the survey was between the ages of $18-25$, and they are student of a college or faculty. The participants were asked to rank 10 different outdoor ornamental plants according to their own favor. At the end of the study, Narcissus sp. (daffodil) and Chaenomeles japonica (japanese quince) were the most preferred species with $22 \%$ and $2 \%$ respectively. When the preferred properties of plants are examined, fragrance is credited with the highest values $(74 \%)$, whereas visuality with the $(65 \%)$, and coloring with the $(37 \%)$. These results emphasize that the plants to be used in urban green areas should be determined in accordance with their preferability by the users and the use of species that can adapt to the natural environment with their aesthetic and functional characteristics should be expanded.
\end{abstract}

Keywords: User preference, ornamental plants, Kilis, planting design, outdoor.

\footnotetext{
*Sorumlu Yazar (Corresponding Author): 


\section{Giriş}

Bir bireyi veya nesneleri olumlu veya olumsuz bir şekilde değerlendirme eğilimine kadar birçok yönden karşılaştırma sonucu belirlenen yaklaşım tutum olarak ifade edilebilir. Bu yaklaşımlarla ilgili ölçümlerde doğrudan gözlem yapmaktan ziyade genellikle anket yoluyla yapılan sorgulama ve gözlemler tercih edilen yöntemlerdir ( Dawes, 1972; Balram ve Dragicevic,2005). Son yıllarda kent yaşamından kaynaklı olumsuz koşulların insanları olumsuz yönde etkilediği tartışılmaktadır. Doğadan uzaklaşan ve doğal çevre ile teması minimum düzeye inen insanlar, psikolojik ve fizyolojik rahatsızlıklarla karşılaşabilmektedir. Kentsel yeşil alanlar, kentlinin yaşam kalitesini olumlu yönde etkilemesinin yanı sıra, kentin karakterine katkı sağlayan, rekreasyonel kullanım potansiyeli olan alanlardır (Aydemir, 2004). Kentsel bağlamda, rahatlama ve şehrin koşturmacasından uzaklaşma ihtiyacı oldukça güçlüdür. Doğal ortamların sessiz ve adeta zamansız atmosferi, günlük kaygıları unutturan, temiz hava solumanın yanı sıra hem zihinsel hem de fiziksel olarak rahatlamaya imkân sağlayan ortamlardır (Chiesura,2004). Bu anlamda değerlendirildiğinde bugün kentsel yaşamda doğal ortam etkisi oluşturan bitkiler gün geçtikçe daha önemli hale gelmektedir. Kentlerdeki sanayileşmenin çevreye uyumlu olmayışı, insan nüfusunun artışı, yoğun iş hayatı, kent halkının yeşil alan ihtiyacını ve talebini artırmaktadır. Bu sebeple kentsel peyzaj uygulamalarında bitki çeşitliliğine gidilmesi, zorunluluk haline gelmeye başlamıştır (Kayabaşı, 2018). Özellikle, estetik ve işlevsel mekânların tasarlanmasında hiç kuşkusuz bitkiler önemli roller üstlenirler. Bu nedenle yapısal peyzajı oluşturan malzemelerin cansız görünümleri bitkiler gibi canlı, sevimli, bir görünüm sergileyen malzemelerle daha doğal ve insanla uyumlu bir duruma getirilmektedir. (Acar ve ark,2003). Bu nedenle ekolojik koşullara uygun bitki materyalinin seçimi, tasarımın başarısını büyük ölçüde etkilemektedir (Bilgili ve ark,2014).

Bitkiler, bazı tasarım ilkeleri çerçevesinde kompozisyon oluşturacak şekilde kullanılabilmektedirler. Yan yana gelişlerinden, kullanım amaçlarına kadar birçok kompozisyonda bu ilkeler rol oynamaktadır (Eroğlu ve ark,2005). Bunun yanı sıra bitkisel tasarım çalışmalarında renk, doku, form, meyve, çiçek ve mevsimlik renk değişimleri gibi estetik özelliklerinin yanı sıra; gölgeleme, biyolojik onarım, erozyon kontrolü, rüzgâr ve gürültü perdesi oluşturma gibi fonksiyonel özelliklerinden de yararlanılmaktadır (Özer ve ark,2009).

Kilis kenti mevcut şehir alanı sınırları içerisinde yürütülen çalışma, kent sakinlerinin dış mekân süs bitkilerine karşı yaklaşımını, tercihlerini, bu tercihlerde etkili olan temel faktörleri ve kent içerisinde kullanılan bitki türleri ile ilgili düşüncelerini belirlemeyi amaçlamıştır. Bu bulguların, kent içerisinde yapılacak olan bitkisel tasarım çalışmalarında kullanıcıların da ihtiyaç ve tercihlerini göz önünde bulunduran bir yaklaşım geliştirilmesine katkı sağlayabileceği düşünülmektedir.

\section{Materyal ve Metot}

\subsection{Materyal}

\section{Alanın Sınırlarının Belirlenmesi}

Çalışma Kilis kenti mevcut şehir alanı sınırlarında gerçekleştirilmiştir. Yüzölçümü 1,521 km² olan Kilis $36^{0} 37^{1}$ ile $37^{\circ} 01^{1}$ kuzey enlemleri ve $36^{0} 45^{1}$ ile $37^{\circ} 34^{1}$ doğu boylamları arasında yer almaktadır. Akdeniz iklim bölgesinde yer alan kentin deniz seviyesinden ortalama yükseltisi $680 \mathrm{~m}$, ortalama sıcaklık $17.2^{\circ} \mathrm{C}$ iken yıllık yağış toplam miktarı 492.4 mm' dir (MGM,2019).

Kilis nüfusu 2018 yılı itibariyle 142.541'dir (TUIK, 2019). Suriye sınırında bulunan kent, tarihi niteliklere sahiptir ve pek çok kültür varlığı içermektedir. 


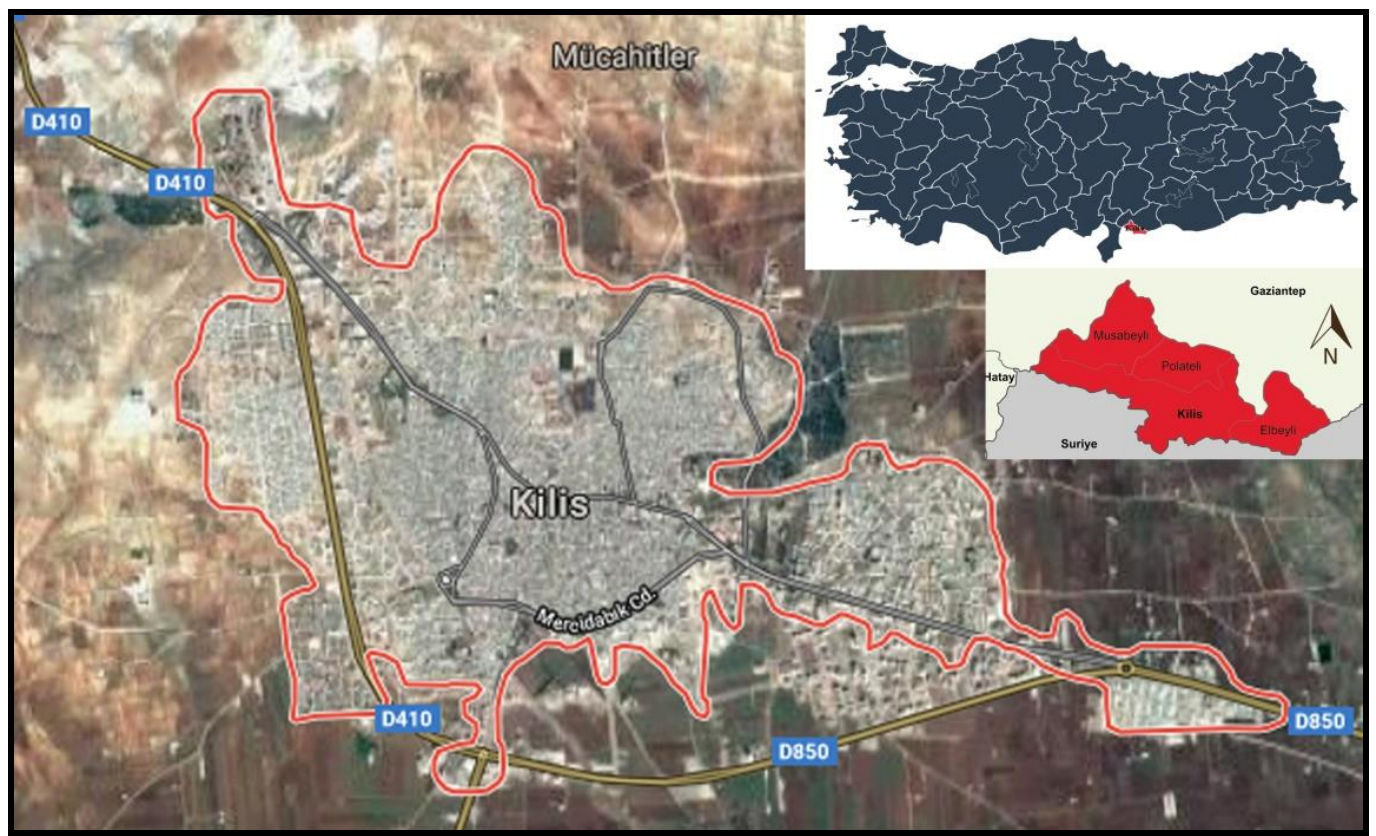

Şekil 1. Mevcut Şehir Alanının Bölgedeki ve Türkiye İçerisindeki Konumu

\subsection{Metot}

\section{Kullanıcı Araştırmasında Anket Formlarının Oluşturulması ve Uygulanması}

Anket formları, tesadüfi olarak seçilen 100 denek üzerinde uygulanmış ve katılımcıların en az 3 senedir kentte ikamet ediyor olmasına dikkat edilmiştir.

Çalışmada tercih ve memnuniyet düzeyleri ile temel eğilimlerinin ortaya konulması amacıyla, kullanıcı araştırması gerçekleştirilmiş̧ir. Bu doğrultuda oluşturulan anket formu iki bölüm ve 11 sorudan oluşmaktadır. İlk bölümde yaş, cinsiyet, eğitim durumu gibi kullanıcı profiline yönelik kişisel bilgiler yer almakta, ikinci bölümde katılımcıların dış mekân süs bitkilerine ait tespitleri yer almaktadır.

İkinci bölümde çoktan seçmeli ve açık uçlu sorular yer almaktadır. İlk aşamada, belirlenen süs bitkilerine ait 10 adet fotoğraf kullanıcılara sunulmuştur. Bu bitkiler sahada yapılan tespitler neticesinde Pinus pinea (fistık çamı), Albizia julibrissin (gülibrişim), Phoenix canariensis (yalancı hurma), Lagestromia indica (oya), Chaenomeles japonica (bahar dalı) Buxus sempervirens (șimșir), Lampranthus roseus (acem halısı), Sedum album (dam koruğu), Tulipa sp.(lale) Narcissus sp.(nergis) olarak belirlenmiştir. Bu aşama kullanıcıların bitkileri biçim, renk, ölçü ve doku öğeleri açısından değerlendirerek, beğenilerine göre sıralama yapmalarını sağlamaya yöneliktir. İkinci aşamada ise bitki tercihlerinde etkili olan genel ve işlevsel özelliklerin tespit edilmesine öncelik verilmiştir. Sonraki aşamada ise kullanıcılardan deneyimleri ve bilgi birikimleri doğrultusunda, kendi bahçelerinde yer alan bitkileri belirtmeleri istenmiştir. Fiziksel ve estetik özelliklerin kullanıcıların tercihleri üzerinde etkisinin olduğu düşünüldüğünde, bunlardan hangilerinin ne ölçüde etkili olduğunu belirlemek için verilen cevaplar yorumlanarak tartışılmaya çalışılmıştır. Son aşamada ise, kullanıcıların kent içerisinde yer alan açık ve yeşil alanlar ile ilgili görüş ve önerileri alınarak yorumlanmıştır.

\section{Sayısal Analiz}

Kullanıcı araştırmasında anket yöntemiyle elde edilen veriler sayısal olarak değerlendirilmiş ve oransal bulgular elde edilmiştir.

\section{Bulgular ve Tartışma}

Katılımcıların çoğu (\%41) 18-25 yaş aralı̆̆ında ve genç bir yaş ortalamasına sahiptir. Ayrıca \%65 oranında erkek katılımcı bulunmaktadır (Şekil 2). 


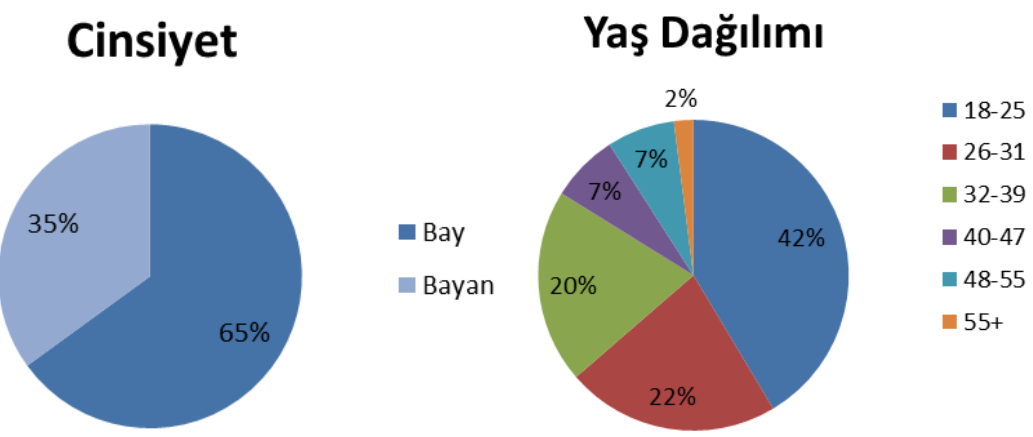

Şekil 2. Katılımcıların cinsiyet ve yaş dağılımları

Katılımcıların medeni durumu incelendiğinde \%58'inin bekar, \% 42'sinin ise evli olduğu belirlenmiştir. Meslek dağılımlarında ise \%39 ile öğrenci en yüksek orana sahipken emekli oranı ise \%2'dir (Şekil 3).
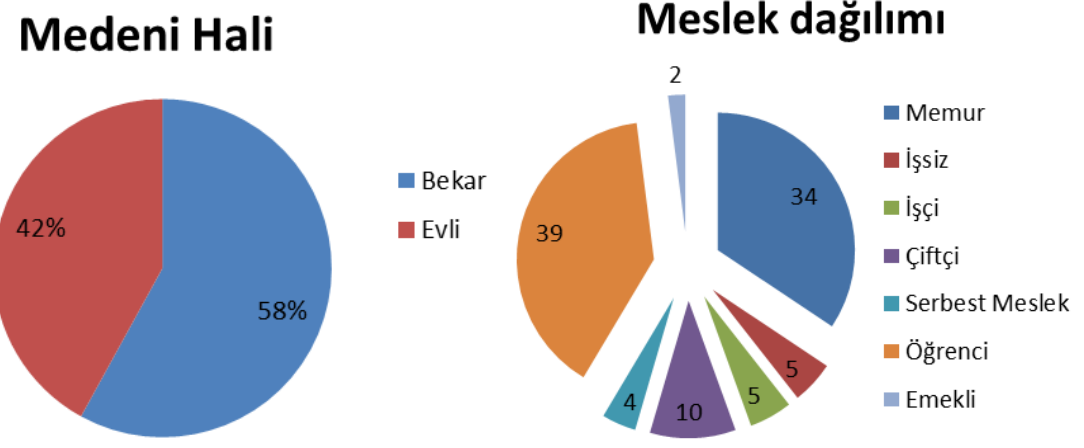

Şekil 3. Katılımcıların medeni hali ve meslek grubu dağılımları

Ankete katılanların\% 42'si üniversite eğitimi alırken,\% 2'si ise okuryazar değildir. İkamet süresi olarak değerlendirildiğinde ise en yüksek oran \% 37 ile 3 y1l, en düşük oran ise \%13 ile 7-9 yıl olarak tespit edilmiştir (Şekil 4).

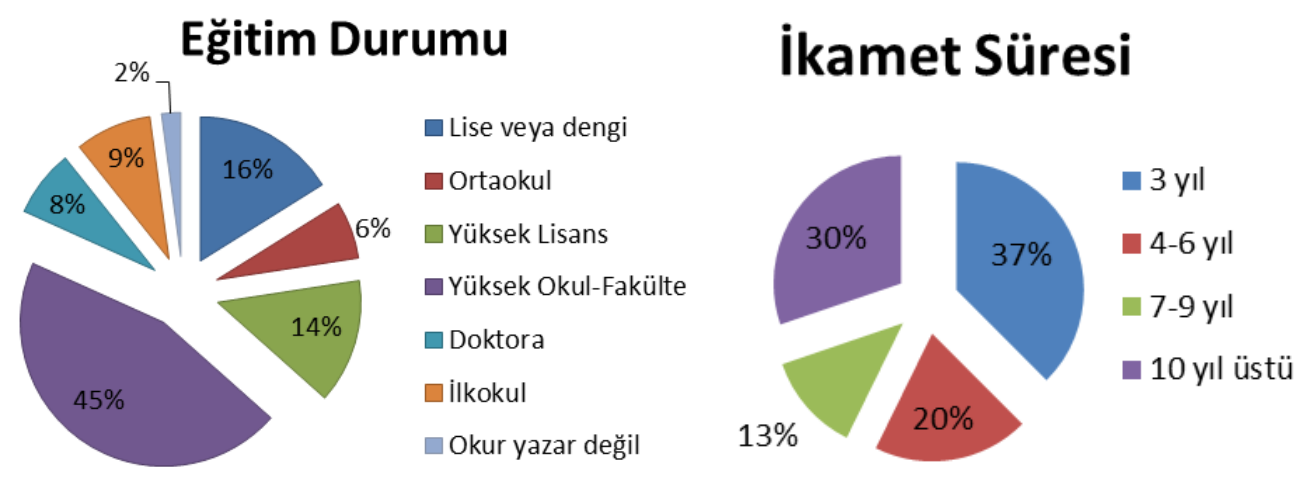

Şekil 4. Katılımcıların eğitim durumu ve ikamet süresi dağılımları

İkinci bölümün ilk aşamasında, belirlenen süs bitkilerine ait 10 adet fotoğraf kullanıcılara sunulmuştur. Bu aşamada kullanıcıların bitkileri beğenilerine göre sıralamaları sağlanmaya çalışılmıştır. Seçilen türler herdem yeşil ve yaprak döken türleri içermekte olup, bunlar ağaç-ağaçcık, çalı, yer örtücü ve soğanlı türleri kapsamaktadır.

Çalışmada belirlenen ve beğeniye göre sıralanması istenen 10 adet bitki türünden çiçek özelliği olan türlerin tercih oranının daha yüksek olduğu belirlenmiştir. İlk sırada tercih edilme durumu incelendiğinde, Narcissus sp.(nergis) türü \%22 ile en yüksek orana sahipken, bunu \%15 ile Tulipa sp.(lale) ve \%13 ile Lagestromia indica (oya) türleri takip etmiştir (Şekil 5).En az tercih edilen tür ise \%2 oranı ile Chaenomeles japonica (bahar dalı)dır. En yüksek 
orana sahip türün çiçek ve koku özelliğine sahip olmasının, beğeni oranını arttırıcı bir etki oluşturduğu düşünülmektedir. Kullanıcıların tercihleri incelendiğinde, çiçekli türlerin daha çok tercih edildiği söylenebilir.

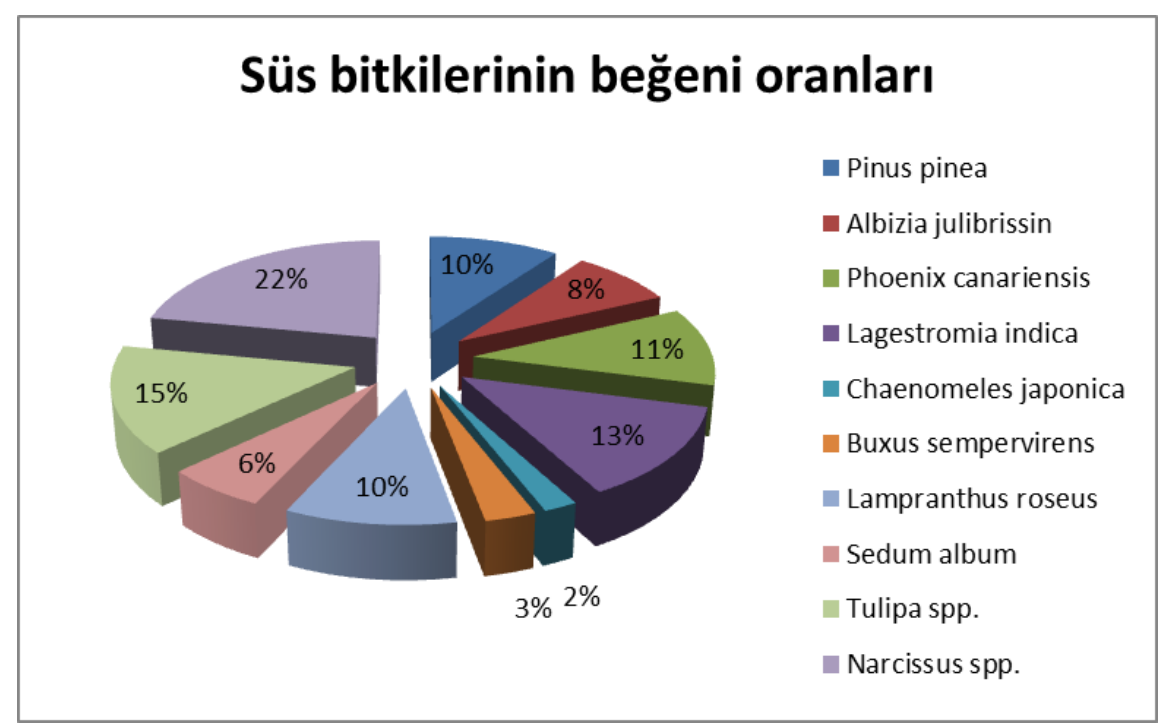

Şekil 5. Bitki türlerinin beğeni durumuna göre dağılımı

Süs bitkilerinde tercih edilen özellikler kullanıcılar açısından incelendiğinde, kokulu olması (\%74), görsellik (\%65), renkli olması (\%37) olarak sıralanmaktadır. En düşük değere (\%1) sahip özellikler arasında ise boyu, çiçek şekli, yapay olmaması, su isteğinin az olması, uzun dönem çiçekli olması, besin değeri, dört mevsim canlı olması, huzur verici olması, toprağı koruması, kuru ve yaş kullanım, çiçek şekli yer almaktadır (Şekil 6).

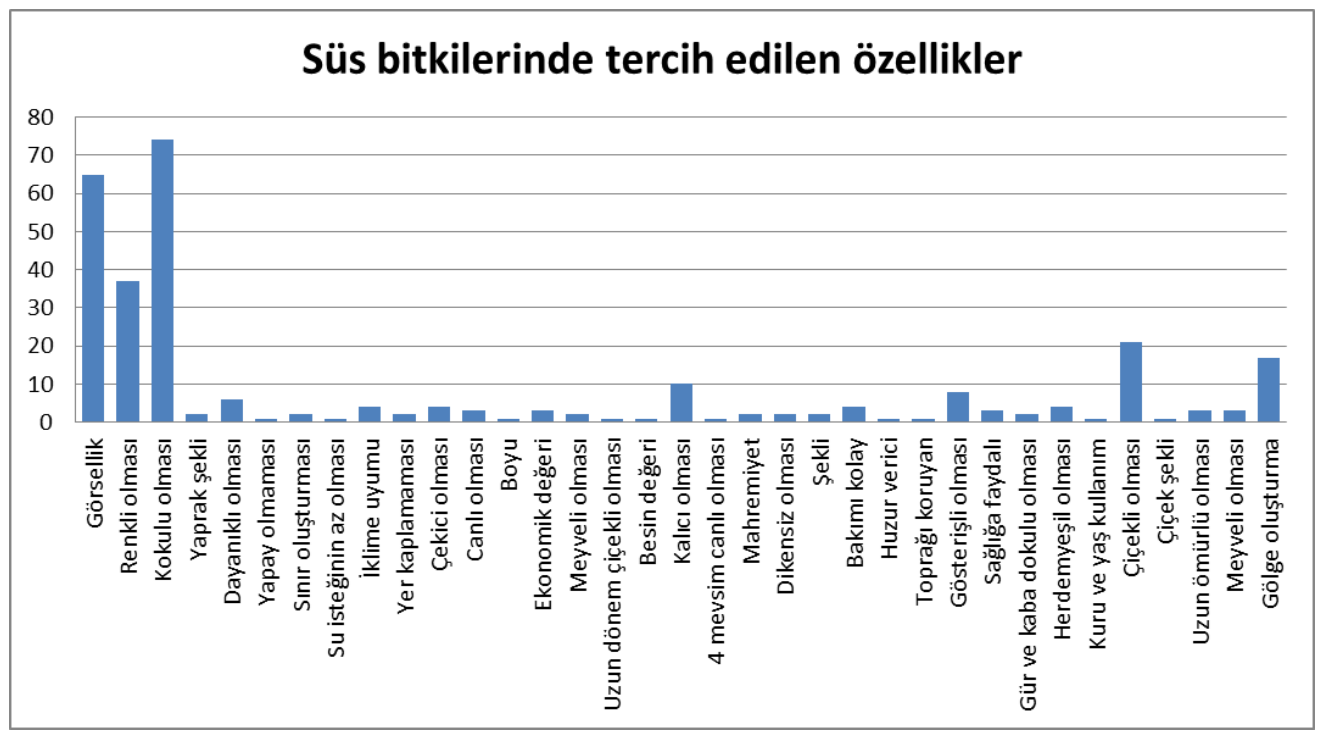

Şekil 6. Bitki türlerinde tercih edilen özellikler

Süs bitkilerinin sahip oldukları fonksiyon (ișlev) özellikleri incelendiğinde ise, katılımcıların \%91'i koku, \%90'ı görsel ve estetik, \%66'sı çiçek özelliği, \%59'u gölge etkisi, \%35'i ekonomik değeri ve sonbahar renklenmesi, \%32'si erozyon önleme, \%26'sı sınır oluşturma,\%25'i su tutma kabiliyeti, \%21'i mahremiyet oluşturma, \%16'sı besin değeri yanıtını vermiş, en düşük değer ise yönlendirme (\%7) olarak tespit edilmiştir (Şekil 7). Bu durum görsel olarak beğeni sıralaması yapılan aşamadaki sonuçlarla da (Şekil 5) uyumlu görünmekte ve kullanıcıların koku özelliği olan türleri daha çok tercih ettiğini ifade etmektedir. 


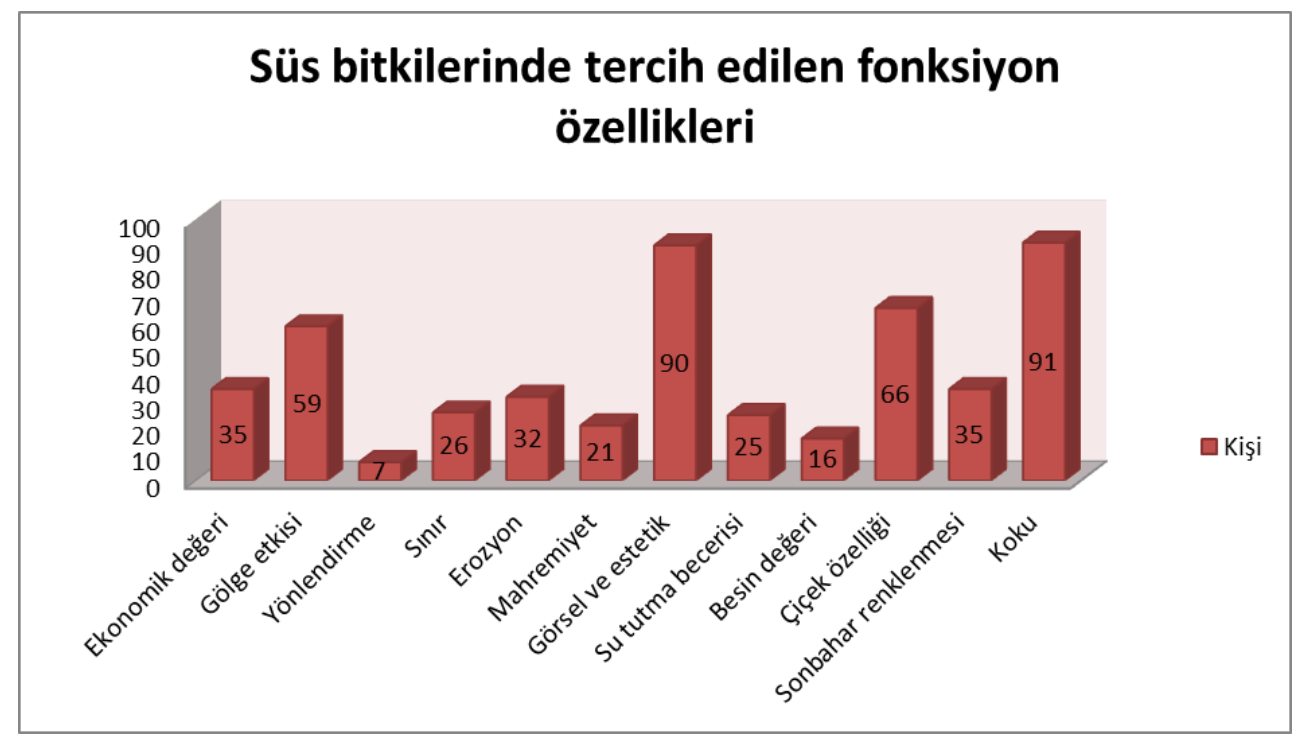

Şekil 7. Bitki türlerinin fonksiyon özelliklerine göre tercih dağılımı

Yukarıda sonuçları verilen durum, bireysel olarak kendi bahçelerinde yer alan türler açısından değerlendirildiğinde, tercih edilen türler içerisinde en yüksek oran \%63 ile Rosa sp. (gül) türüne aittir. Bununla birlikte \% 36 ile Tulipa sp.(lale) 2. sırada yer almaktadır. En düşük oran ise \%1 ile Kalanchoe sp.(kalanşo), Schefflera sp.(şeflera) ve Aleo vera türüne aittir (Şekil 8).

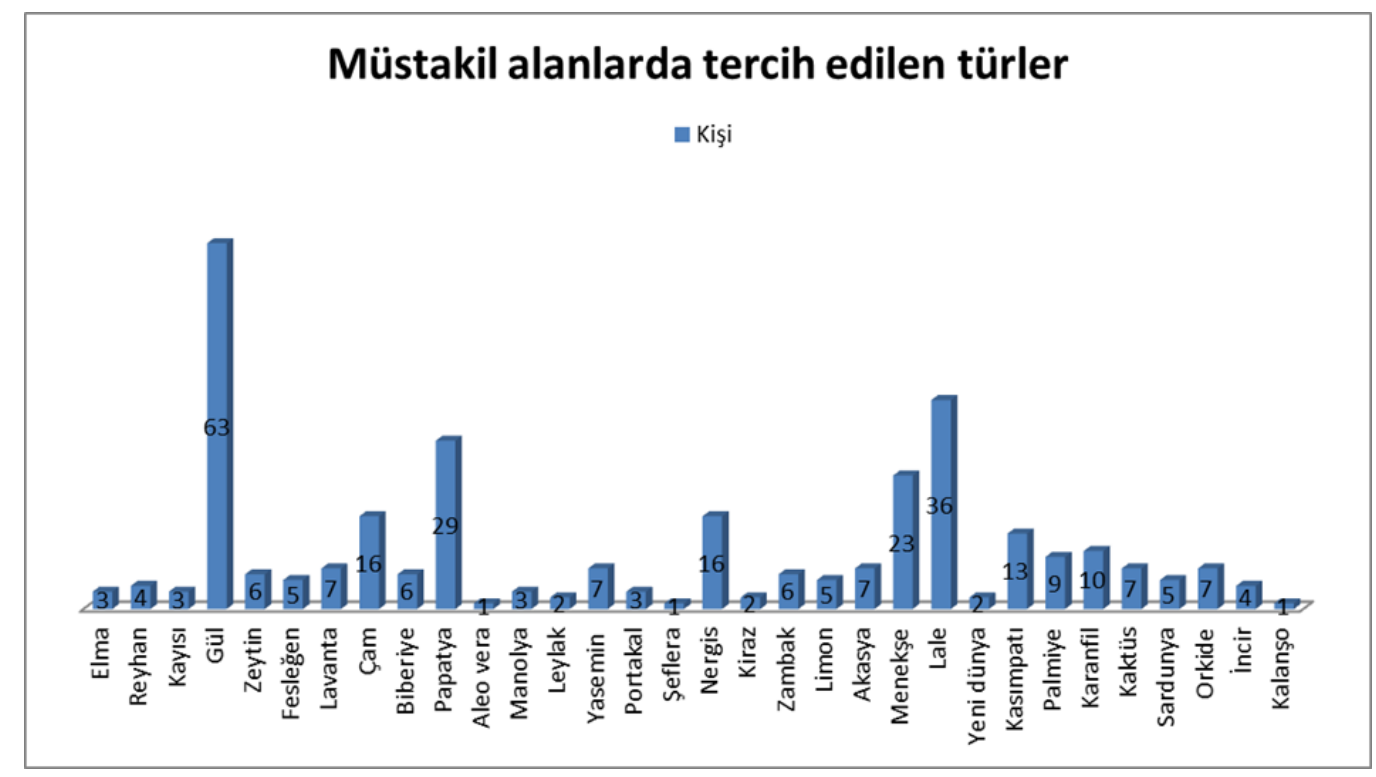

Şekil 8. Müstakil alanlarda kullanılan bitki türlerinin dağılımı

Açık ve yeşil alanlarla ilgili öneri ve görüş bölümünde, yeşil alan bakımları sürekli olmalı (\% 15), yeterince yeșil alan bulunmamakta (\%13) ve kent içi yeșil alanlar arttırılmalı (\%10) olarak sıralanmaktadır. Buna karşılık \% 1 oranında yeterli miktarda yeşil alan olduğunu ifade eden görüşler de tespit edilmiştir (Çizelge 1). 
Çizelge 1. Kent içi bitkisel tasarım uygulamalarla ilgili görüş ve öneri dağılımları

\begin{tabular}{|c|c|c|c|c|c|c|c|c|c|}
\hline $\begin{array}{c}\text { Yeşil alan } \\
\text { bakımları sürekli } \\
\text { olmalı }\end{array}$ & 15 & $\begin{array}{l}\text { Güzel ama daha } \\
\text { çok özen } \\
\text { gösterilmeli }\end{array}$ & 2 & $\begin{array}{l}\text { Sonbaharda } \\
\text { renklenen türler } \\
\text { kullanılmalı }\end{array}$ & 1 & $\begin{array}{c}\text { Açık alanlar } \\
\text { ağaçlandırılmalı }\end{array}$ & 1 & $\begin{array}{l}\text { Mevsim etkisini } \\
\text { yansitması }\end{array}$ & 1 \\
\hline $\begin{array}{l}\text { Yeterince yeşil alan } \\
\text { bulunmamakta }\end{array}$ & 13 & $\begin{array}{l}\text { Parklarda } \\
\text { aydınlatmalar } \\
\text { yetersiz }\end{array}$ & 2 & $\begin{array}{c}\text { Toprak alanlar } \\
\text { bitkilendirilmeli }\end{array}$ & 1 & Fikrim yok & 1 & $\begin{array}{l}\text { Çevreye daha çok } \\
\text { önem verilmeli }\end{array}$ & $\mathbf{1}$ \\
\hline $\begin{array}{c}\text { Kent içi yeşil } \\
\text { alanlar arttırılmalı }\end{array}$ & 10 & $\begin{array}{c}\text { Çevrenin } \\
\text { renklendirilmesi } \\
\text { sağlanmalı }\end{array}$ & 2 & $\begin{array}{l}\text { Oluşturulan yeşil } \\
\text { alanlar iptal } \\
\text { edilmemeli }\end{array}$ & 1 & $\begin{array}{c}\text { Kent içerisinde } \\
\text { bitki } \\
\text { bulunmamakta }\end{array}$ & 1 & $\begin{array}{l}\text { Düzenlemelerin çoğu } \\
\text { özensiz yapılmakta }\end{array}$ & 1 \\
\hline $\begin{array}{l}\text { Koruma önlemleri } \\
\text { alınmalı }\end{array}$ & 9 & $\begin{array}{c}\text { Üniversitedeki } \\
\text { uygulamalar gibi } \\
\text { olmalı }\end{array}$ & 2 & $\begin{array}{l}\text { Yeşil alan eksikliği } \\
\text { halkı olumsuz } \\
\text { etkilemekte }\end{array}$ & 1 & $\begin{array}{c}\text { Yeterince yeşil alan } \\
\text { var }\end{array}$ & 1 & $\begin{array}{l}\text { Görsel olarak çok } \\
\text { güzel uygulamalar }\end{array}$ & 1 \\
\hline $\begin{array}{l}\text { Güzel bir görünüm } \\
\text { sağlanmalı }\end{array}$ & 8 & $\begin{array}{c}\text { Yapılan } \\
\text { çalışmalar güzel } \\
\text { ama az }\end{array}$ & 2 & $\begin{array}{l}\text { Yeşil alanların } \\
\text { bakımına özen } \\
\text { gösterilmeli }\end{array}$ & 1 & $\begin{array}{l}\text { Meyveli türlere yer } \\
\text { verilmeli }\end{array}$ & 1 & $\begin{array}{l}\text { Parklar sayı olarak } \\
\text { çok ancak küçük }\end{array}$ & 1 \\
\hline $\begin{array}{c}\text { İnsanlar yeşil } \\
\text { alanlar ile ilgili } \\
\text { bilinçlendirilmeli }\end{array}$ & 7 & $\begin{array}{l}\text { Çok yaprak ve } \\
\text { çiçek dökmeyen } \\
\text { türler seçilmeli }\end{array}$ & 2 & $\begin{array}{l}\text { Halktan öneri } \\
\text { alarak işbirliği ile } \\
\text { düzenleme } \\
\text { yapılmalı }\end{array}$ & 1 & $\begin{array}{l}\text { Çim alanlar } \\
\text { arttırılmalı }\end{array}$ & 1 & $\begin{array}{l}\text { Uygulamalara estetik } \\
\text { bitki türleri eklenmeli }\end{array}$ & 1 \\
\hline $\begin{array}{l}\text { Uzun süre kalıcı } \\
\text { türler seçilmeli }\end{array}$ & 6 & $\begin{array}{l}\text { İnsan tahribat1 } \\
\text { engellenmeli }\end{array}$ & 2 & $\begin{array}{l}\text { Daha iyi } \\
\text { düzenlemeler } \\
\text { yapılabilir }\end{array}$ & 1 & $\begin{array}{l}\text { Bakıma ihtiyaç } \\
\text { duymayan türler } \\
\text { seçilmeli }\end{array}$ & 1 & $\begin{array}{l}\text { Çamlar çok, güller } \\
\text { çok az kullanılmış }\end{array}$ & 1 \\
\hline $\begin{array}{l}\text { Kokulu türler } \\
\text { seçilmeli }\end{array}$ & 6 & $\begin{array}{l}\text { Uzun dönem } \\
\text { çiçek açan türler } \\
\text { seçilmeli }\end{array}$ & 2 & $\begin{array}{l}\text { Düzenli sulama } \\
\text { yapılmalı }\end{array}$ & 1 & $\begin{array}{l}\text { Ezilmeye dayanıklı } \\
\text { türler seçilmeli }\end{array}$ & 1 & $\begin{array}{c}\text { Şehirde büyük bir } \\
\text { yeşil alan } \\
\text { oluşturulmalı }\end{array}$ & 1 \\
\hline $\begin{array}{c}\text { Kalıcı olmayan } \\
\text { türler maddi olarak } \\
\text { zararlı }\end{array}$ & 6 & $\begin{array}{l}\text { Görsel etkisi } \\
\text { olan türlerin } \\
\text { seçilmeli }\end{array}$ & 2 & $\begin{array}{c}\text { Şehirde oturacak } \\
\text { herhangi bir yer } \\
\text { bulunmamakta }\end{array}$ & 1 & $\begin{array}{c}\text { Aromatik } \\
\text { bitkilerden maddi } \\
\text { kazanç sağlanmalı }\end{array}$ & 1 & $\begin{array}{c}\text { Belediyenin } \\
\text { uygulamalarından } \\
\text { memnunun }\end{array}$ & 1 \\
\hline $\begin{array}{l}\text { Sadece gül ve lale } \\
\text { türleri dikilmekte }\end{array}$ & 6 & $\begin{array}{l}\text { Kokulu türlerin } \\
\text { kullanımı } \\
\text { arttırılmalı }\end{array}$ & 2 & $\begin{array}{c}\text { Sadece üniversitede } \\
\text { yeşil alan ve bitki } \\
\text { var }\end{array}$ & 1 & $\begin{array}{c}\text { Çevre daha yeşil } \\
\text { olmalı }\end{array}$ & 1 & $\begin{array}{l}\text { Hayvanlar için yaşam } \\
\text { alanını destekleyen } \\
\text { düzenlemeler } \\
\text { yapılmalı }\end{array}$ & 1 \\
\hline $\begin{array}{l}\text { Estetik, kokulu ve } \\
\text { dikkat çekici türler } \\
\text { seçilmeli }\end{array}$ & 5 & $\begin{array}{l}\text { Mevsimlik } \\
\text { bitkiler daha az } \\
\text { kullanılmalı }\end{array}$ & 2 & $\begin{array}{l}\text { Ülke ekonomisine } \\
\text { katkı sağlayacak } \\
\text { türler kullanılmalı } \\
\text { ve yetiştirilmeli }\end{array}$ & 1 & $\begin{array}{l}\text { Uygulamaların } \\
\text { çoğunun gereksiz } \\
\text { olduğunu } \\
\text { düşünüyorum }\end{array}$ & 1 & $\begin{array}{c}\text { Uygulamalarda } \\
\text { kullanılan bitkiler tür } \\
\text { olarak } \\
\text { çeşitlendirilmeli }\end{array}$ & 1 \\
\hline $\begin{array}{l}\text { Estetik ve koku } \\
\text { özelliğiyle huzur } \\
\text { veren türler } \\
\text { seçilmeli }\end{array}$ & 3 & $\begin{array}{c}\text { Lale ve } \\
\text { menekşelerin } \\
\text { kullanımı şehire } \\
\text { güzellik katıyor }\end{array}$ & 2 & $\begin{array}{l}\text { Kente uygun bitki } \\
\text { türleri seçilmeli }\end{array}$ & 1 & $\begin{array}{c}\text { Şehirde yeterli } \\
\text { miktarda süs bitkisi } \\
\text { bulunmakta }\end{array}$ & 1 & & \\
\hline $\begin{array}{c}\text { Süs bitkileri çeşit } \\
\text { ve sayı olarak } \\
\text { arttırılmalı }\end{array}$ & 3 & $\begin{array}{l}\text { Park sayıs1 } \\
\text { arttırılmalı }\end{array}$ & 2 & $\begin{array}{l}\text { Yeşil alanlar } \\
\text { düzensiz }\end{array}$ & 1 & $\begin{array}{c}\text { Belediyenin } \\
\text { çalışmaları yetersiz }\end{array}$ & 1 & & \\
\hline $\begin{array}{l}\text { Koku ve renklerin } \\
\text { insana hitap etmesi } \\
\text { gerekli }\end{array}$ & 3 & $\begin{array}{l}\text { Parkları temiz } \\
\text { tutacak önlemler } \\
\text { alınmalı }\end{array}$ & 2 & $\begin{array}{l}\text { Bazı türler ekmiş } \\
\text { olmak için ekilmiş }\end{array}$ & 1 & $\begin{array}{l}\text { Temiz hava } \\
\text { oluşumuna destek } \\
\text { olacak türler } \\
\text { seçilmeli }\end{array}$ & 1 & & \\
\hline $\begin{array}{l}\text { Su ihtiyacı az olan } \\
\text { türler seçilmeli }\end{array}$ & 2 & $\begin{array}{c}\text { Yaprak } \\
\text { dökmeyen türler } \\
\text { seçilmeli }\end{array}$ & 1 & $\begin{array}{l}\text { Düzensiz yerleşim } \\
\text { ve uygulamalar var }\end{array}$ & 1 & $\begin{array}{c}\text { Renkli ve çeşitli } \\
\text { türler var ancak } \\
\text { yetersiz }\end{array}$ & 1 & & \\
\hline $\begin{array}{l}\text { Yeşil alanlar } \\
\text { bakımsız }\end{array}$ & 2 & $\begin{array}{l}\text { İşçilik ve maliyet } \\
\text { azaltılmalı }\end{array}$ & 1 & $\begin{array}{l}\text { Bitkiler görsel } \\
\text { olarak zayıf }\end{array}$ & 1 & $\begin{array}{l}\text { Kalıcı türlere daha } \\
\text { çok yer verilebilir }\end{array}$ & 1 & & \\
\hline $\begin{array}{l}\text { Uzun süre kalıcı } \\
\text { türler seçilmeli }\end{array}$ & 2 & $\begin{array}{l}\text { Gölge alanlar } \\
\text { oluşturulmalı }\end{array}$ & 1 & $\begin{array}{c}\text { Daha işe yarayacak } \\
\text { yeşil alanlar } \\
\text { yapılmalı }\end{array}$ & 1 & $\begin{array}{l}\text { Yeşil alanlar daha } \\
\text { çok kullanılır hale } \\
\text { getirilmeli }\end{array}$ & 1 & & \\
\hline
\end{tabular}




\section{Sonuç ve Öneriler}

Kentsel açık alan tasarımında, kullanıcı görüş ve tercihlerinin önemi büyüktür. Kent sakinlerinin dış mekân süs bitkileri tercihlerinin ve yaklaşımlarının belirlenmesi amacıyla, kentsel yeşil alanların tasarımında yaygın olarak kullanılan ve kullanılmayan, yaklaşık 10 adet dış mekân süs bitkisi türü ile ilgili çok değişkenli bilgi toplanmıştır. Çiçek taşıyan bitki türleri katılımcılara herdemyeşil süs bitkilerinden daha çekici gelmiş, Narcissus sp.(nergis), Tulipa sp.(lale) ve Lagestromia indica (oya) türleri en yüksek tercih oranına sahip olan türler olarak belirlenmiştir. Chaenomeles japonica(bahar dalı) bitkisinin çiçekli olması ve yapraklanmadan önce çiçeklenme özelliğiyle dikkat çekmesine rağmen kullanıcılar tarafından en az tercih edilme oranına sahip olması ise sonuçlar açısından nispeten şaşırtıcı olarak ifade edilebilir.

Acar ve Sarı (2010)'da yaptıkları çalışmada, görsel ve estetik özellikler başta olmak üzere, bitkilerin fonksiyonel ve ekolojik özelliklerinin, peyzajda kullanım tercihlerini belirlediğini ifade etmişlerdir.

Balram ve Dragiçeviç (2005) ise çalışmasında halkın kentsel yeşil alanlara karşı etki ve fayda olmak üzere iki faktörlü bir yaklaşımının olduğunu belirlemiştir. Araştırmada belirlenen yanıtların bu anlamda çalışma ile tutarlı olduğu söylenebilir.

Erzurum kentinde yapılan bir araştırmanın sonucunda ise, kent halkının dış mekân süs bitkilerine talebi oldukça fazla olduğu tespit edilmiştir. Kent halkı; güzel görünümlü süs bitkilerini (392 puan), yaprak-çiçek ve gövde güzelliğine sahip bitkileri (587 puan) ve fonksiyonelliği açısından da gölge oluşturabilen bitkileri (422 puan), görmek ve kullanmak istemektedirler (Yılmaz ve Zengin, 2003). Tekirdă̆'da yapılan çalışmada ise kent halkının, \%31'i kullanılan bitkilerin estetik olmasını isterken, sadece \%10'u fonksiyonel olmasını istemektedir. Ankete katılanların \%24’ü için bitkilerin çiçek-yaprak-gövde güzelliği önem taşımakta, dolayısıyla Tekirdağ halkı için tasarım bitkilerinin estetik özelliklerinin önem taşıdığı söylenebilmektedir (Yılmaz,2006). Bu anlamda araştırmamızın bulguları, Erzurum ve Tekirdağ'da yapılan çalışmaların bulgularıyla uyumlu olup, estetik özelliklerin ön planda tutulduğunu destekler niteliktedir.

Aslan ve arkadaşlarının (2013) Malatya kentinde yürüttüğü çalışmanın sonucunda kent halkının büyük oranda gölge yapan türleri tercih ettiği belirlenmiştir. Bu oranlar; gölge \%53.1, havayı temizleme \%15.2, mahremiyet $\% 11.9$, erozyon önleme \%6.7 ve gürültüyü önleme \%5.7 olarak tespit edilmiştir. Gölge oluşturma tercihinin yüksek olması, bölgede özellikle yaz aylarında söz konusu olan yüksek sıcaklıklar ve güneşli gün sayısının fazla olmasından kaynaklandığı düşünülmüştür. Çalışma bulgularında ise \% 59 oranında gölge etkisi yanıtı belirlenmiş, en yüksek oranlar ise \%91 ile koku, \%90 görsel ve estetik olarak belirlenmiştir. Bu durum iklim olarak yazın yüksek değerlere ulaşan kentte gölge ihtiyacından ziyade estetik kaygıların daha önemli olduğunu destekler niteliktedir.

Rahnema ve arkadaşları (2019) İran'da yaptıkları çalışma sonucunda, süs bitkileriyle karşılaşan insanların huzur ve rahatlama hissettiklerini belirlemiştir. Ayrıca katılımcılar çiçek taşıyan bitki türlerini daha çok tercih etmiş, kırmızı renk ise en çok tercih edilen çiçek rengi (\% 52.1) olarak belirlenmiştir. Çalışmamız, ilgili araştırma ile çiçekli türlerin daha fazla tercih edilmesi yönüyle tutarlılık göstermektedir.

Özellikle iklim ve bitki örtüsü olarak değerlendirildiğinde çok çeşitli bitki türünün kullanıldığını söylemek zor olsa da, son yıllarda özellikle kent içi bitkisel tasarım çalışmalarında, çiçek açan ve renk özelliğiyle ön planda olan türlerin kullanımında artış yaşanmaya başlamıştır. Bu durum bölgeye uyum sağlayacağı düşünülerek kentte bulunan üniversite kampüsüne dikilen bitki türlerinin adaptasyonu ile bu türlerin kent içerisinde daha yaygın kullanılır hale gelmesi ile bağdaştırılabilir.

Bu bağlamda çalışmada katılımcıların dış mekân süs bitkileri ile ilgili düşünceleri, bitki seçimlerinde öncelikleri, bitkisel tasarım çalışmaları ve bitki türlerine karşı yaklaşımlarının belirlenmesi açısından oldukça önemlidir. Nitekim kullanıcı istek ve görüşleri doğrultusunda şekillenen alanların daha yoğun bir kullanıma sahip olacağı aşikârdır.

\section{Kaynaklar}

1. Acar, C., Sarı, D. (2010). Kentsel Yerleşim Alanlarındaki Bitkilerin Peyzajda Kullanım Tercihleri Açısından Değerlendirilmesi: Trabzon Kenti Örneği, Ekoloji, 19, 173-180.

2. Acar, C., Demirbaş, E., Dinçer, P., Acar, H. (2003). Anlamsal Farklılaşım Tekniğinin Bitki Kompozisyonu Örneklerinde Değerlendirilmesi. Süleyman Demirel Üniversitesi Orman Fakültesi Dergisi, Seri A (1), 15-28. 
3. Aslan, F., Kaya, G., Yılmaz, B., ve Atik, A. (2013). Malatya Kent Halkının Dış Mekan Bitki Tercihlerinin Belirlenmesi Üzerine Bir Araştırma. Social Sciences, 8 (1), 33-49.

4. Aydemir, E.S., Öksüz, A.M., Aydemir, Ş., Beyazlı, D.Ş., Ökten, N., Sancar, C., Özyaba, M., Türk, Y.A. (2004). Kentsel Alanların Planlanması ve Tasarımı, 285-335 s, Trabzon.

5. Balram, S., Dragićević, S. (2005). Attitudes Toward Urban Green Spaces: İntegrating Questionnaire Survey And Collaborative GIS Techniques To İmprove Attitude Measurements. Landscape and Urban Planning. 71, 147-162.

6. Bilgili, B.C., Aytaş, İ., Çorbacı, Ö.L., Alp, Ş. (2014). İlkbaharda Çiçek Açan Bazı Bitki Türlerinin Çankırı Koşullarında Çiçeklenme Zamanlarının Belirlenmesi. Türk Tarım ve Doğa Bilimleri Dergisi, 1(3), 338-347.

7. Chiesura, A. (2004). The Role Of Urban Parks For The Sustainable City. Landscape and Urban Planning, 68(1), 129-138.

8. Dawes, R.M. (1972). Fundamentals of Attitude Measurement. Wiley, New York

9. Eroğlu, E., Akıncı Kesim, G., Müderrisoğlu, H. (2005). Düzce Kenti Açık Ve Yeşil Alanlarındaki Bitkilerin Tespiti Ve Bazı Bitkisel Tasarım İlkeleri Yönünden Değerlendirilmesi. Tarım Bilimleri Dergisi 11, 270-277.

10. Kayabaşı Torun, E. (2018). Kentsel Tasarımda Doğal Bitkilerin Kullanımı ve Ekonomik Önemi. Uluslararası Kentleşme ve Çevre Sorunları Sempozyumu: Değişim/Dönüşüm/Özgünlük.77-84, Eskişehir.

11. Montgomery, C. (2013). Happy City: Transforming Our Lives Through Urban Design Macmillan, New York, USA.

12. MGM (2019). Meteoroloji Genel Müdürlüğü. www.mgm.gov.tr/veridegerlendirme/il-ve-ilceleristatistik.aspx?k=A\&m=KILIS (12.04.2019).

13. Özer, S., Atabeyoğlu, Ö., Zengin, M. (2009). Prunus spinosa L. (Çakal Eriği)'nin Peyzaj Mimarlığı Çalışma Sahasında Kullanım Olanakları. GOÜ Ziraat Fakültesi Dergisi, 26(2), 1-7.

14. Rahnema, S., Sedaghathoor, S., Allahyari, M. S., Damalas. H. A., El Bilali, H. (2019). Preferences And Emotion Perceptions Of Ornamental Plant Species For Green Space Designing Among Urban Park Users İn Iran. Urban Forestry \& Urban Greening. 39, 98-108.

15. TUİK (2019). Türkiye İstatistik Kurumu. www.tuik.gov.tr/PreIstatistikTablo.do?istab_id=1633 (12.04.2019)

16. Yılmaz, S., Zengin, M. (2003). Erzurum Kent Halkının Süs Bitkilerine Olan Talebinin Belirlenmesi. Süleyman Demirel Üniversitesi Orman Fakültesi Dergisi, A 1, 29-42.

17. Yılmaz, R. (2006). Tekirdağ Halkının Tasarım Bitkilerine Olan Talebinin Belirlenmesi Üzerine Bir Araştırma. Tekirdağ Ziraat Fakültesi Dergisi 3, 71-81. 